in Council, been taken over by the Minister of Technology. Under Clause 4 of the Bill the Authority would be able to extend its research functions outside the field of nuclear energy if the Minister of Technology so desired. This would enable the resources of skill, expertise and facilities in the Authority to be made available to support the Ministry in stimulating technological advance in industry if opportunity offered. Viscount Caldecote later suggested that it would be more appropriate to run down any strength not required in the Authority and transfer such highly qualifiod staff elsewhere in industry.

Lord Champion announced that an Order in Council was being laid that day bringing the National Research Development Corporation within the responsibility of the Minister of Technology, and it was hoped to introduce a Bill shortly which would increase the effectiveness of the Corporation. He said that a review was under way to establish the feasibility of orientating purchases and contracts in directions which would aid technological progress, including consideration of purchases made by the authorities directly and indirectly financed from public funds. The Minister of Technology was setting up several technical appraisal teams of scientists, engineers and economists from within and outside the Government service to investigate the performance and products of seetors of industry, to identify any technological weaknesses, and to consider the ways in which these might be remedied. Other methods contemplated were the intensified placing of development contracts with industry, possibly under the supervision of the appropriate research station; steps to improve the supply and status of engineers; action to ensure that in the engineering field the British Standards Institution made the maximum contribution to the objectives of the Ministry. A suggestion from Lord Brown that the universities were themselves mainly responsible for the shortage of technologists and engineers and for failure to expand in this respect was stoutly refuted by Lord Chorley. Lord Snow, agreeing as to the importance of the status of engineers, added that he believed that the use of engineers could be radically improved by constructive action and by attempting to bring into othor parts of industry not used to employing professional skill, the kinds of skill which were already used in the advanced industries.

\title{
THE WELLCOME FOUNDATION, LTD.
}

T was in 1880 that $\mathrm{H}$. S. Wellcome, an American citizen by birth, came to England to partner S. M. Burroughs, and later to form Burroughs Wellcome and Company. On the death of Burroughs, Wellcome assumed sole control of the Company. His flair for commerce (he pioncered largescale manufacture of tablets, with scientifically precise dosage, under the famous trade-mark 'Tabloid'); his drive, his profound belief in research, and his philanthropic outlook, these qualities combined to make possible the Wellcome Foundation and, later under the terms of his will, the Wellcome Trust, ". . . which applies the profits it receives to the advancement of medical and allied sciences and to the establishment or endowment of research museums and libraries throughout the world". The story of this Foundation, unique alike in character and structure, is well told and lavishly illustrated (much in colour) in a new publication*. It is a document of considerable scientific interest and is well worth reading, especially by those concerned with prevention, control and cure of disease.

Although its headquarters are still in the familiar building in Euston Road, London, the ramifications of the Wellcome Foundation, through its subsidiarios and associated companies, Burroughs Wellcome International, Ltd., and Cooper, MeDougall and Robertson, Ltd., are world wide. The chief operating centres are: Canada, Montreal; United States, New York and Chicago; South America, Rio de Janeiro, São Paulo and Buenos Aires; Europe, Paris, Brussels, Rome, Porrino; Africa, Nairobi, Salisbury and Johannesburg; Asia, Karachi and Bombay; Australia, Sydney; and Now Zealand, Auckland. Prominence is given in this brochure to the Research Laboratories in the United Kingdom at Beckenham, Kent (Langley Court); to the Chemical Works at Dartford, Kent; and to the Veterinary Research Station at Frant, Kent. Many of the products of Cooper, MeDougall and Robertson, Ltd., acquired by the Foundation in 1959, are manufactured in the Kelvindale factory, Glasgow, but the Cooper Technical Bureau is maintained at Berkhamsted, Hertfordshiro, wherein is conducted research on insecticides, parasitic and bacterial diseases of animals, animal nutrition, chemical manufacture and pressure packing. Here, too, is the focus of collecting and recording scientific information. Some illustrated details are also

* The Wellcome Foundation, Ltd. Pp. 52. (London: The Wellcome Foundation, Ltd., 1964.) briefly given of the activities of the Company's overseas houses.

It is, however, when we come to examine some of the many outstanding achievements of the Foundation over the years that the impressive service it has rendered to mankind and animals becomes clearly manifest. As long ago as 1894 it was the first British company to produce diphtheria antitoxin. During 1904-14, Sir Henry Dale, then director of research, discovered and investigated histamine, acetylcholine and sympathomimetic amines, and showed how nerve impulses are transmitted. During 1921 the principles forming the basis of all methods of immunization were outlined. The period 1927-31 witnessed the discovery of diphtheria vaccines A.P.T. and T.A.F., also digoxin ('Lanoxin'); this was when the company introduced dog distemper prophylactics. In 1933 it was ". . . discovered that maternal antibodies in sheep are transferred from ewe to lamb in the first milk. From this have come the present-day methods of protecting lambs against many killing infections". In 1938 came the discovery of the antibacterial effects of sulphones, to-day the chief agents for treating leprosy. Between 1939 and 1949 came the discoveries of globin zinc insulin; the antibiotic polymyxin $B$ ('Aerosporin', 'Thiosporin'); the pharmacology of suxamethonium (succinylcholine), the short-acting muscle relaxant ('Anectine', 'Midarine'); and the issue of the first pure tubocurarine ('Tubarine'), the muscle relaxant for major surgical operations. In the decade 1952-62 were discovered the anti-cancer drug, mercaptopurine ('Puri-nethol'), the antimalarial pyrimethamine ('Daraprim'), the anthelmintic bephenium ('Alcopar', 'Frantin'); and in 1962 azathioprine ('Imuran'), making possible transplantation of kidneys. In 1963 the company introduced methisazone ('Marboran'), the first antiviral chemotherapeutic compound, effective against smallpox.

This is a proud record. It is a remarkable tribute to that "blend of science, business and philanthropy" envisaged by the founder, Sir Henry Wellcome, LL.D., D.Sc., F.R.S., as he was when he died in 1936. In the Truman Wood Lecture to the Royal Society of Arts in 1963, Prof. E. B. Chain said: "Rarely can a contribution from a University laboratory have exceeded in theoretical or practical importance the discoveries which originated in the Wellcome Physiological Research Laboratories" (now part of the Wellcome Research Laboratories). 